\title{
Habitat characteristics and relative abundance of the mud crab Scylla serrata (Forskål, 1775) in Lawele Bay, Southeast Sulawesi, Indonesia
}

\author{
La Sara*1 • Riza O. Aguilar² • Jose A. Ingles ${ }^{3}$ • Liberato V. Laureta ${ }^{2}$ \\ ${ }^{1}$ Department of Fisheries, Faculty of Fisheries and Marine Sciences, Halu Oleo University, Kampus Baru Anduonohu, Kendari, 93232 Southeast Sulawesi, \\ Indonesia \\ ${ }^{2}$ College of Fisheries and Ocean Sciences, University of the Philippines in the Visayas, Miagao, Iloilo, Philippines \\ 3World Wildlife Fund (WWF) Philippines, 65 Mindanao Ave., Pag-asa, Quezon City 1105, Philippines \\ *Corresponding author: lasara_unhalu@yahoo.com
}

\section{How to cite this paper:}

Sara, L., Aguilar, R.O., Ingles, J.A., Laureta, L.V., 2014. Habitat characteristics and relative abundance of the mud crab Scylla serrata (Forskål, 1775) in Lawele Bay, Southeast Sulawesi, Indonesia. Ege J Fish Aqua Sci 31(1): 11-18. doi: 10.12714/egejfas.2014.31.1.03

\begin{abstract}
Based on similarity of natural features of salinity, turbidity, soil substrate, mangrove vegetations and intertidal flat of the stations studied, there were three habitats (A, B, and C) of Scylla serrata (Forskål, 1775) in Lawele Bay. The characteristics of habitat A were preferred by S. serrata since it had the highest relative abundance of $\mathbf{S}$. serrata. With relative abundance of $11.87 \%$, habitat $\mathbf{B}$ as transition habitat between habitats $\mathbf{A}$ and $\mathbf{C}$ was less preferred by $\mathbf{S}$. serrata. The characteristics of habitat $\mathbf{C}$ were in contrary with habitat $\mathbf{A}$ and $S$. serrata caught was only $1.19 \%$.

The relative abundance of $S$. serrata at habitat $\mathbf{A}$ differed significantly with habitats $\mathbf{B}$ and $\mathbf{C}(p<0.05)$, while at habitat $\mathbf{B}$ was not significantly different with habitat $\mathbf{C}(p>0.05)$. It suggests that $S$. serrata tended to move forward at habitat $\mathbf{A}$ and occupying such habitat which was characterized by low salinity, high turbidity, the thickest mangrove vegetation, muddy substrate and the widest intertidal flat. The relative abundance of males was significantly different with females either during flood tide or ebb tide $(p<0.05)$. Both sexes had two peaks of abundance. A major peak was in July and August and a minor peak in February. The lowest relative abundance was in December. However, seasonal relative abundance was not significantly different $(p>0.05)$. It suggests that the relative abundance may depend on seasons but they are found all year round.
\end{abstract}

Keywords: Habitat characteristics, Relative abundance, Scylla serrata, Peak season

\section{INTRODUCTION}

Habitats of mud crab Scylla (De Haan, 1833) such as S. serrata are generally found in mangrove waters and estuaries. Estuaries are characterized by high turbidity, total suspended solid (TSS) and water salinity fluctuation. Therefore, habitats of mud crab are affected by several environmental factors, which in turn affect abundance and distribution of mud crabs. Salinity, temperature and sediment characteristics are generally considered to be the major factors that limit the distribution of invertebrates (Hsueh, 1998; Mair, 1980; Weinstein et al., 1980; Islam et al., 2000). Temperature affects activity and feeding of adult of $S$. serrata when temperature falls below $20^{\circ} \mathrm{C}$ (Hill 1980) despite being eurythermic fauna (Joel and Ray, 1980). It was stated that optimum light is believed to be the major factor in the distribution of the species S. serrata. The light penetration depends on total suspended solid concentration in the water column.

The largest individuals of $S$. serrata are always found nearest to the mangroves waters (La Sara, 1994; 1995; La Sara, 2001a) and juveniles are commonly found in tidal flats, marshy coastal land and mangrove waters. Mangroves are known for their role as suitable nursery grounds (Chandrasekaran and Natarajan, 1994). Likewise, life of mud crabs are probably dependent on mangrove forest.
There are several studies on habitats of mud crab (Hill, 1975; 1980; Joel and Ray, 1980; Hill et al., 1982; Hyland et al., 1984; Chandrasekaran and Natarajan, 1994; La Sara, 1994; 1995; 2001a). The authors and among others identified the specimens of mud crabs as $S$. serrata, but it might not be S. serrata since a revision of genus Scylla appeared in 1995 (Keenan et al., 1995). The recent publication of S. serrata population dynamics was authored by La Sara (2010). The present study is to identify and to verify habitats of $S$. serrata and to determine its relative abundance at different habitats in Lawele Bay.

\section{MATERIALS AND METHOD}

The study was carried out in Lawele Bay $\left(122^{\circ} 50^{\prime}\right.$ $123^{\circ} 05^{\prime} \mathrm{E}$ and $5^{\circ} 05^{\prime}-5^{\circ} 20^{\prime} \mathrm{S}$ ) in the eastern part of the main island of Buton, Southeast Sulawesi (Figure 1). It is surrounded by thick mangrove areas of $0.2-1.1 \mathrm{~km}$ wide along the shoreline, composing of Rhizophora spp., Bruguiera spp. and Nypa spp. In addition, it is affected by five main rivers, namely Lawele, Sinapuli, Mompenga, Batuawu and Rawa Rivers on the eastern and southern sections and Banda Sea on the northern section. The western section is fully 
affected by seawater from Banda Sea, while the eastern section is mainly affected by river outflows and tributaries, hence water salinity varies depending on the season. Water salinity drops to lower levels of $0.7-3.0$ ppt during north monsoon and reaches up to 30 ppt during south monsoon. The southern section of the bay receives both seawater and freshwater so its salinity is higher than that in the eastern section. Soil texture of the bay varies in both sections. In the western section, soil texture is composed of sandy loam, silt clay loam, crushed and dead corals, while the eastern section is dominated by silt (muddy substrate). Soil substrate in the southern section is dominated by clay loam.

The above-mentioned characteristics were used as criteria for the selection of sampling stations and sampling design. Ten sampling stations were established (Figure 1). Stations at lower salinity with muddy substrate were represented by stations 1 - 4. The size of this sampling stations was approximated $715.85 \mathrm{Ha}$. Stations $6-7$ had moderate salinity and clay loam of substrate, while stations 5 and 8 - 10 had high salinity and crushed and dead coral of substrate. The size of those sampling stations was approximated $271.39 \mathrm{Ha}$, $80.57 \mathrm{Ha}$ and $481.40 \mathrm{Ha}$, respectively. Stations 9 - 10 were located in seagrass bed near coral reef area.

Sampling of mud crab from all stations was conducted monthly at the time of flood and ebb tides using baited traps and gill nets. At each station, twenty traps baited with fish were dropped $20 \mathrm{~m}$ to $30 \mathrm{~m}$ apart for about $4 \mathrm{~h}$. Similarly, gill net was set in the same station. This gear is monofilament with mesh size of $3 \mathrm{~cm}$. The mud crabs caught by fishermen from each station were monitored monthly.

All samples of mud crabs were measured as to their carapace width $(\mathrm{CW})$ and length $(\mathrm{CL})$ using a caliper to the nearest $0.1 \mathrm{~mm}$, wet weighed using balance to the nearest 1 $\mathrm{g}$, counted and identified to species level (Keenan et al., 1995; 1988; Keenan, 1999). Water parameters such as water depth, temperature, salinity, turbidity and TSS were measured at all stations at the time of mud crabs collections. The physical soil parameter measured was soil texture. Soil samples were taken at low tide using a modified core sampler of PVC pipe.

Habitats of $S$. serrata were classified based on similarity of salinity, turbidity, soil substrate, mangrove vegetation and intertidal flat of each station. After the habitats were established, percentage abundance of mud crabs caught monthly from each habitat was calculated from the total catch of each sex. Monthly relative abundance (the total number of mud crabs caught per total gears used in a month) was determined from the entire catches (Kyomo, 1999). Differences in relative abundance of mud crabs among months, habitat types and tidal phase according to the sex of mud crab were analyzed using ANOVA (Zar, 1984). The Duncan's multiple range test was used for multiple comparison where there were significantly ANOVA results.

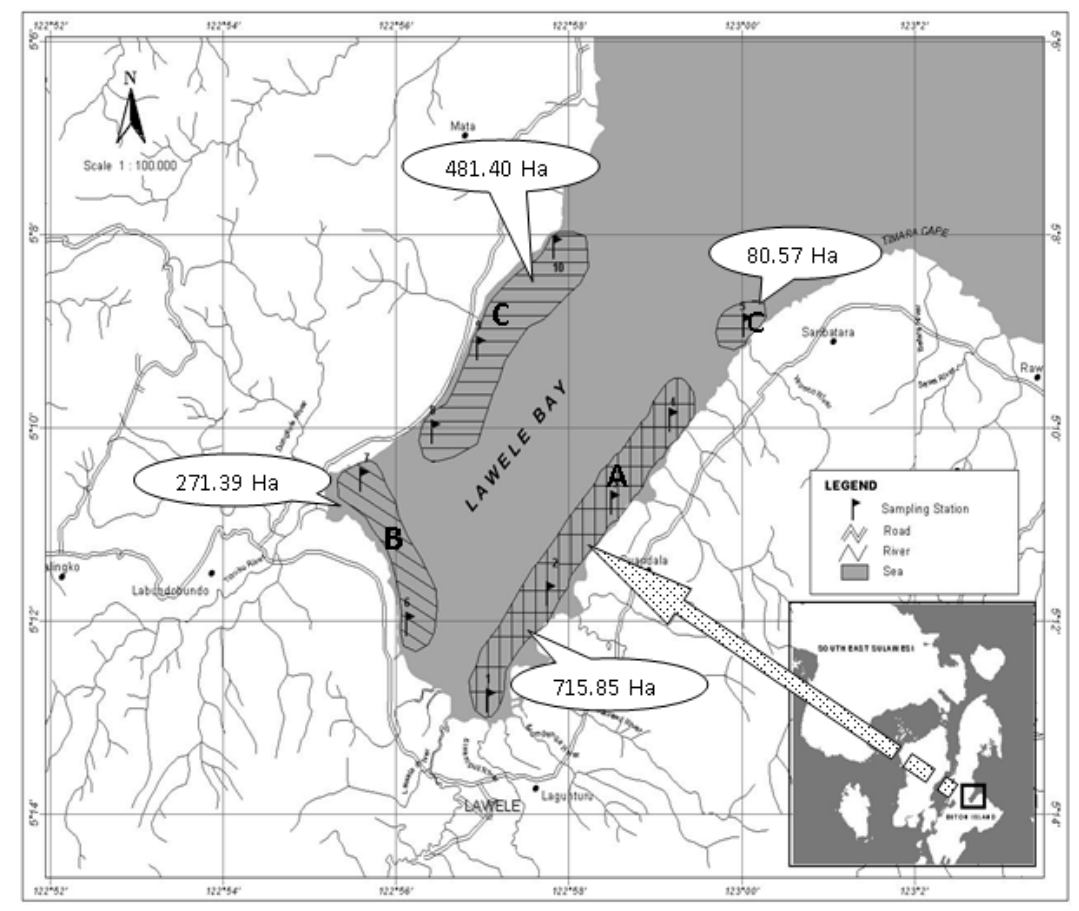

Figure 1. Sampling stations and the cluster of habitat of mud crab Scylla serrata in Lawele Bay, Southeast Sulawesi $(A=$ station 1 to $4 ; B=$ station 6 to $7 ; B=$ station 5,8 to 10$)$ 


\section{RESULTS AND DISCUSSION}

\section{Habitat Characteristics of S. serrata}

The natural features of the stations studied in Lawele Bay as habitat of $S$. serrata were classified into three habitats based on salinity, turbidity, substrate, mangrove vegetations and intertidal flat (Table 1 and Figure 1). Water parameters measured at each habitat fluctuated following seasons (Figures 2 and 3). Water depth at habitat $\mathbf{A}$ during flood and ebb tides ranged from $92.25 \mathrm{~cm}$ to $196.75 \mathrm{~cm}$ and from 41.68 $\mathrm{cm}$ to $140.76 \mathrm{~cm}$, respectively, while at habitat $\mathrm{B}$ ranged from $83.00 \mathrm{~cm}$ to $290.00 \mathrm{~cm}$ and from $47.50 \mathrm{~cm}$ to $126.67 \mathrm{~cm}$, respectively. Those water depths at habitat $\mathbf{B}$ were shallower than habitat $\mathbf{C}$ but deeper than habitat $\mathbf{A}$. The deepest water depth was at habitat $\mathbf{C}$ ranging from $126.25 \mathrm{~cm}$ to $354.18 \mathrm{~cm}$ during flood tide and from $56.25 \mathrm{~cm}$ to $162.50 \mathrm{~cm}$ during ebb tide. Temperature showed very close values and similar trend at all habitats either during flood or ebb tides. Its values were $27-32^{\circ} \mathrm{C}$. TSS in the respective habitat fluctuated in the wide range. It dropped to lower level in December and increased sharply in January (rainy season). Its values at habitat A, B and $\mathbf{C}$ during flood tide were fairly similar, namely 184.88 $866.68 \mathrm{mg} / \mathrm{l}, 31.00$ - $1027.50 \mathrm{mg} / \mathrm{l}$ and 388.50 - $973.58 \mathrm{mg} / \mathrm{l}$, respectively. During ebb tide, its values differed between habitat types namely 205.63 - $902.50 \mathrm{mg} / \mathrm{l}, 330.75-798.50$ $\mathrm{mg} / \mathrm{l}$ and $388.50-973.58 \mathrm{mg} / \mathrm{l}$, respectively.

According to those natural features, three habitats (symbolized by A, B, and C, Fig. 1) of S. serrata in Lawele Bay were classified. Stations in the eastern and western sections formed habitats $\mathbf{A}$ and $\mathbf{C}$, respectively, while stations in the southern section as transition habitat between habitat types $\mathbf{A}$ and $\mathbf{C}$ formed one habitat type, habitat $\mathbf{B}$. Habitat $\mathbf{A}$ had low salinity and high turbidity. Rhizophora and Bruguiera were dominant covering $200-1100 \mathrm{~m}$ width. These species generally grow in less saline condition with muddy substrate (Bunt et al., 1982). Despite S. serrata to be an euryhaline animal and can tolerate salinity of $2-60 \mathrm{ppt}$ and survive in pure fresh water (Hill, 1975; Islam and Bhuiyan, 1982; La Sara, 1994; Davenport and Wong, 1986), all stages of S. serrata preferred low salinity which were always found in brackish water and mangrove areas (La Sara, 1994; 1995). Adult S. serrata during flood and ebb tides in Segara Anakan lagoon, Central Java were found in salinity of $4.8-7.5$ ppt and $1.9-2.3$ ppt, respectively (La Sara, 1994), while salinity in mangrove areas ranged from 2 ppt to 34 ppt (Wahyuni and Sunaryo, 1981) and 0 ppt to 18 ppt (Wahyuni and Ismail, 1981).

The existence of mangroves was important for $S$. serrata and other crustaceans. The number of trees, saplings, and seedlings of mangrove in Lawele Bay differed according to habitat types. The average number of those mangrove types at habitat $\mathrm{A}$ was 286.64 trees $/ \mathrm{Ha}, 632.28$ trees $/ \mathrm{Ha}$, and $2,611.16$ trees/ $\mathrm{Ha}$, respectively. Those mangrove types at habitat B were around 50\% from habitat A namely 116.07
trees/Ha, 262.45 trees $/ \mathrm{Ha}$, and 1,016.26 trees $/ \mathrm{Ha}$, respectively. At habitat $\mathbf{C}$, the number of those mangrove types was very low namely 36.70 trees/Ha, 90.89 trees/Ha, and 104.08 trees/Ha, respectively. Adult $S$. serrata population were firmly bound to particular mangrove estuaries (Hill, 1982; La Sara, 1994; 1995; 2001a; 2001b). Juveniles tended to shelter in mangrove roots and adult females have a burrow just beneath mangrove roots in Lawele Bay. Large individuals were always caught nearest to mangrove area in Segara Anakan lagoon, Central Java which has muddy substrate (La Sara, 1994; 1995). S. serrata tended to occupy mangrove area because it provides suitable nursery ground for juveniles (Chandrasekaran and Natarajan, 1994) and food such as slow moving benthic organisms (Hill, 1976; Chandrasekaran and Natarajan, 1994; La Sara, 2001a), macrophyte and pneumatophore (Hutching and Saenger, 1987; La Sara, 2001a; La Sara et al., 2007). Other crustacean such as Penaeus merguiensis (De Maan, 1888) is closely associated with mangrove vegetation (Chong and Sasekumar, 1981; Staples et al., 1985; Robertson and Duke, 1987). The yield of shrimp fisheries in Indonesia is closely correlated with the abundance of mangrove forest (Martosubroto and Naamin, 1977). This phenomenon is also found in mud crabs.

The intertidal flat in an estuary may provide much food and wide space for feeding, mating and escaping. S. serrata are mostly found in confines of intertidal flat for mating and seek food (Hill, 1979). Intertidal flat with soft mud and muddy substrate are mostly preferred by $S$. serrata. $S$. serrata as well as other mud crabs were distributed principally in relation to soil texture (Whiting and Moshiri, 1974). In South Africa, S. serrata density was higher in areas with mud bottoms than those of sand (Hill 1979). Whiting and Moshiri (1974) reported that distribution patterns of crabs had been dealt with substrate composition as an ecological factor influencing its habitat choice. Marsh crab Sesarma reticulatum (Say, 1817) which was observed in an experiment tended to prefer muddy substrate exclusively (Seiple, 1979). Hence, it suggests that a wide range of intertidal flat with muddy substrate, thickest mangrove vegetations and low salinity were preferred by $S$. serrata. Mud crabs are generally found in turbid water or muddy. Optimum light into water column was believed to be the major factor in the distribution of the species $S$. serrata (Joel and Ray 1980). S. serrata in laboratory showed a very strong negative reaction to light (Hill, 1980). Similarly, an observation on various sizes of $S$. serrata placed in big container at a dark room showed that $S$. serrata gave high reaction when the light was switched on. All these characteristics explained were found at habitat $\mathbf{A}$ and appeared to be preferred by $S$. serrata since its relative abundance was higher than the other two habitats. 

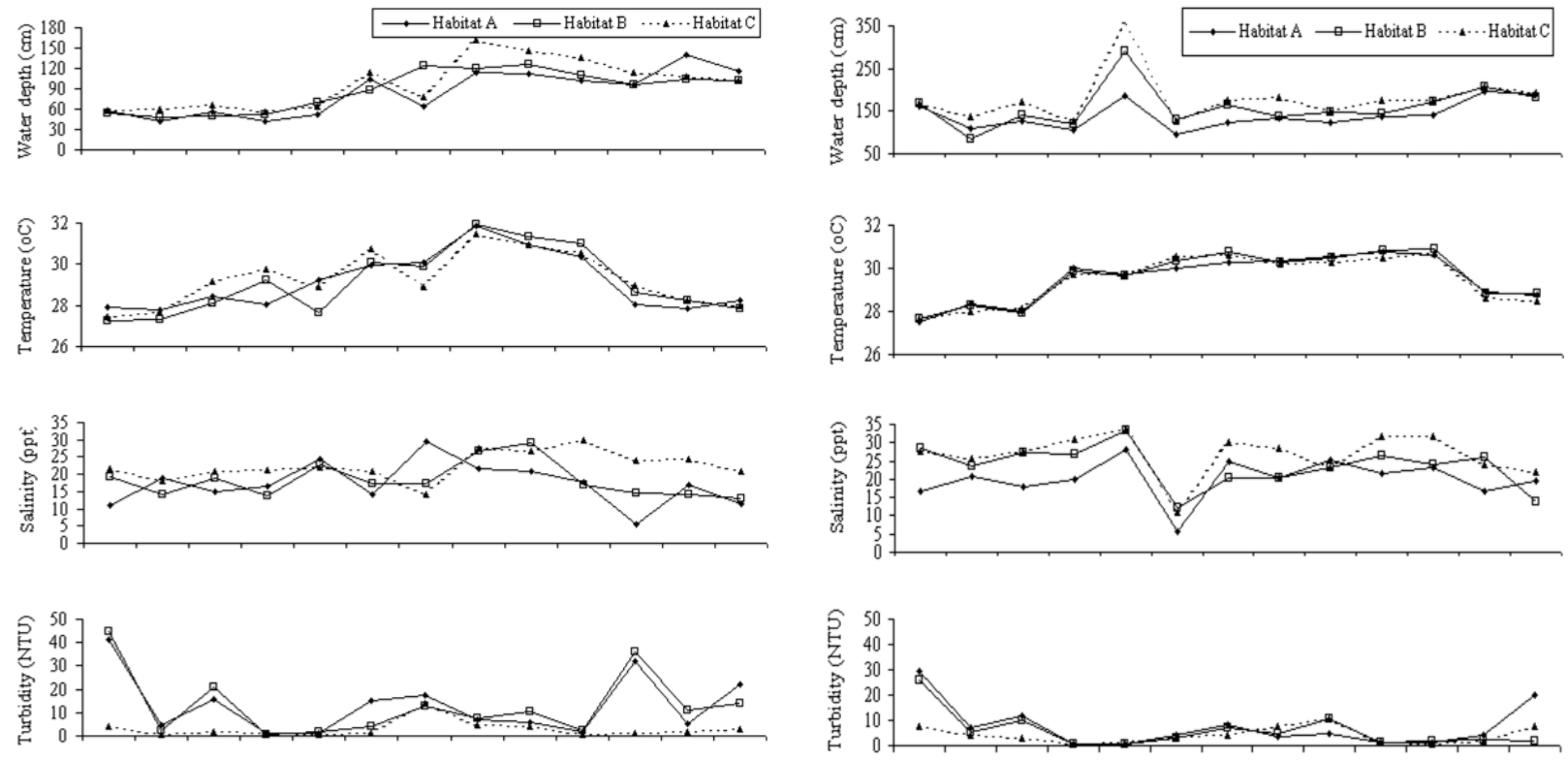

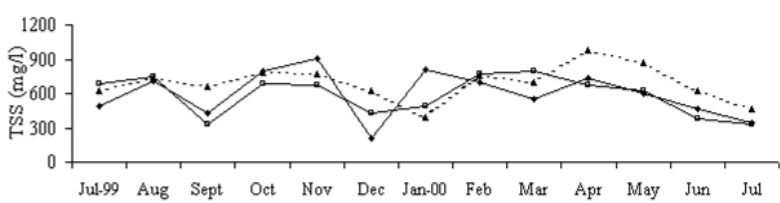

Fig.2. Water parameter measured at each habitat during flood tide in Lawele Bay, Southeast Sulawesi

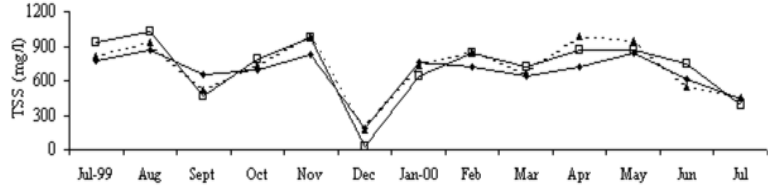

Fig.3. Water parameter measured at each habitat during ebb tide in Lawele Bay, Southeast Sulawesi

Table 1. Description of habitat characteristics of Scylla serrata in Lawele Bay, Southeast Sulawesi

\begin{tabular}{|c|c|c|c|c|c|c|c|}
\hline \multirow{2}{*}{ Habitat } & \multirow{2}{*}{ Station } & \multicolumn{6}{|c|}{ Characteristics } \\
\hline & & Water type & Salinity & Turbidity & Substrate & Vegetation & Intertidal flat \\
\hline A & $1-4$ & $\begin{array}{l}\text { mainly } \\
\text { affected by } \\
\text { river outflow }\end{array}$ & $\begin{array}{l}\text { generally low: } 3.0 \text { - } 30.3 \mathrm{ppt} \\
(20.1 \pm 8.6 \text { ) during flood } \\
\text { tide and } 0.7-31.7 \mathrm{ppt}(17.2 \\
\pm 7.0 \text { ) during ebb tide. The } \\
\text { lowest was at station } 1: 3.0 \\
-21.7 \text { ppt during flood tide } \\
\text { and } 0.7-25.3 \text { ppt during } \\
\text { ebb tide, and the highest } \\
\text { was at station } 4: 5.0-30.3 \\
\text { ppt during flood tide and } 9.3 \\
-31.7 \text { ppt during ebb tide }\end{array}$ & $\begin{array}{l}\text { high: } 0.20-53.89 \text { NTU } \\
(7.46 \pm 10.52) \text { during } \\
\text { flood tide and } 0.30- \\
72.60 \text { NTU }(13.07 \pm \\
16.20) \text { during ebb tide. } \\
\text { The highest and the } \\
\text { lowest was at station } 1 \\
\text { and station } 4 \text {, } \\
\text { respectively }\end{array}$ & $\begin{array}{l}\text { dominated by silt } \\
\text { (muddy } \\
\text { substrate) }\end{array}$ & $\begin{array}{l}\text { dominated by } \\
\text { Rhizophora and } \\
\text { Bruguiera ( } 300- \\
1100 \text { m width) }\end{array}$ & $\begin{array}{l}\text { the widest } \\
\text { intertidal flat: } 20 \text { - } \\
300 \mathrm{~m} \text { (the } \\
\text { narrowest and the } \\
\text { widest was at } \\
\text { station } 4 \text { and } 1 \text {, } \\
\text { respectively) }\end{array}$ \\
\hline B & $6-7$ & $\begin{array}{l}\text { Affected by } \\
\text { both } \\
\text { seawater } \\
\text { and } \\
\text { freshwater }\end{array}$ & $\begin{array}{l}\text { lower than habitat } A: 10.7 \text { - } \\
34.0 \text { ppt }(23.6 \pm 6.3) \text { during } \\
\text { flood tide and } 6.7-30.0 \mathrm{ppt} \\
(18.3 \pm 7.4) \text { during ebb tide }\end{array}$ & $\begin{array}{l}\text { lower than habitat A: } \\
0.25-44.63 \text { NTU }(5.67 \\
\pm 8.98) \text { during flood } \\
\text { tide and } 0.35-72.33 \\
\text { NTU }(13.00 \pm 18.62) \\
\text { during ebb tide }\end{array}$ & $\begin{array}{l}\text { dominated by } \\
\text { clay loam }\end{array}$ & $\begin{array}{l}\text { dominated by } \\
\text { Rhizophora and } \\
\text { Bruguiera (some } \\
\text { have been cut } \\
\text { off) }\end{array}$ & narrow: 25 - $40 \mathrm{~m}$ \\
\hline C & $\begin{array}{l}5,8- \\
10\end{array}$ & $\begin{array}{l}\text { mainly } \\
\text { affected by } \\
\text { seawater } \\
\text { from Banda } \\
\text { Sea }\end{array}$ & $\begin{array}{l}\text { generally high (higher than } \\
\text { habitats } A \text { and } B): 9.67 \text { - } \\
34.3 \text { ppt }(26.8 \pm 6.4) \text { during } \\
\text { flood tide and } 4.7-30.3 \mathrm{ppt} \\
(22.5 \pm 5.9) \text { during ebb tide }\end{array}$ & $\begin{array}{l}\text { the lowest (lower than } \\
\text { habitats A and B): } 0.20 \\
-22.80 \text { NTU }(4.11 \pm \\
4.66) \text { during flood tide } \\
\text { and } 0.20 \text { - } 22.20 \text { NTU } \\
(4.11 \pm 4.66) \text { during } \\
\text { ebb tide }\end{array}$ & $\begin{array}{l}\text { dominated by } \\
\text { sandy loam } \\
\text { (stations } 8-10 \text { ), } \\
\text { silt clay loam } \\
\text { (station } 5 \text { ) and } \\
\text { crushed and } \\
\text { dead corals } \\
\text { Seagrass bed } \\
\text { (near coral reef } \\
\text { area) } \\
\text { represented by } \\
\text { stations } 9 \text { and } 10\end{array}$ & $\begin{array}{l}\text { few Rhizophora } \\
\text { and Bruguiera } \\
\text { (stations } 5 \text { and } \\
8 \text { ) and few } \\
\text { Avicenia in front } \\
\text { of stations } 9 \text { and } \\
10\end{array}$ & no intertidal flat \\
\hline
\end{tabular}


Habitat $\mathbf{B}$ has mangrove vegetations similar with those at habitat $\mathbf{A}$, but has narrow intertidal flat with its substrate being dominated by clay loam. This habitat was affected by both fresh and seawater and had moderate salinity and turbidity levels. While salinity range and mangrove vegetations were fairly preferred by $S$. serrata, its other factors might not be suitable. This was due to heavy exploitation of its mangrove which might partly caused disturbance to $S$. serrata habitat. The low number of $S$. serrata catches at this habitat during the study suggest that this type of habitat might be less preferred.

The characteristics of habitat $\mathbf{C}$ were in contrary with habitat $\mathbf{A}$. This habitat was mainly affected by seawater which led to higher salinity and lower turbidity. The substrate is composed of sandy loam, silt clay loam, crushed and dead corals. This kind of substrate was not preferred by $S$. serrata since it is hard to burrow when escaping from its enemy during molting and after copulation for soft-shell females.

Mangrove vegetations at stations 5 and 8 (habitat $\mathbf{C}$ ) were scarce. This indicates that habitat of $S$. serrata was heavily disturbed. The presence of seagrass bed at stations 9 and 10 is clearly not a habitat for adult $S$. serrata since only one individual was caught by trap throughout the year. It was presumably just for feeding as shown in its gastric mill content (La Sara, 2001a; La Sara et al., 2007). This fact was in accordance with the information from fishermen that only Portunus sp. can be caught at seagrass bed. This finding is rather different from that reported by Chandrasekaran and Natarajan (1994) that juvenile crabs seem to prefer algae bed. The small number of $S$. serrata catch (12 individuals) at habitat $\mathbf{C}$ during the course of study suggest that this habitat type is not preferred.

\section{Relative Abundance of S. serrata}

Monthly catches of $S$. serrata during flood tide was higher than that during ebb tide and were significantly different $(p<$ 0.05). The highest and the lowest total number of both sexes were at habitat $\mathbf{A}$ and habitat $\mathbf{C}$, respectively. Male was always found at all habitats. Females during flood and ebb tides were not caught at habitat $\mathbf{C}$, while males were only eight and four individuals, respectively (Figures 4 and 5). The relative abundance of both sexes at habitat $\mathbf{A}$ were significantly different with habitats $\mathbf{B}$ and $\mathbf{C}(p<0.05)$. It was realized that the abundance of crabs is often affected by method of collection (Kyomo, 1999). However, the gears used in the present study were the most practical and widely used for catching crabs both commercially and experimentally (Robertson, 1989).

The relative abundance of male $S$. serrata in the present study was always higher than females at all habitats. The reason was unclear, but apparently there was phenomenon that male S. serrata and $S$. tranquebarica (Fabricius, 1798) preponderated over female at several coastal waters in Southeast Sulawesi (La Sara, 2001b). This gender bias could be related with two reasons, since most females and males $S$. serrata caught in Lawele Bay were at their adult stage. First, the low catch or even the absence of females might either subject to massive natural mortality including that from predation (Hill 1994). Predation from co-species might happen, particularly after copulation where female's exoskeleton is still soft. $S$. serrata is very vulnerable to be preyed during molting (La Sara, 2001a). He also reported that in Lawele Bay there occurred predation of $S$. serrata from its natural enemies of monitor lizards and wild pigs. In Madagascar coast fresh remains of $S$. serrata was found in the stomach of tiger shark (Hill, 1994). Second, they might have migrated to spawn to seawater (Hill et al., 1982; Heasman et al., 1985; Hill, 1994; La Sara, 2001a; La Sara et al., 2006). Heasman et al. (1985) have reported ovigerous $S$. serrata to be found in deep water up to $80 \mathrm{~km}$ offshore in northern Australia and return to the coast after these females spent ovaries. In several monthly observations in Lawele Bay, there were berried females $S$. serrata floating feebly following current direction which was about $30-50 \mathrm{~km}$ far away from the study areas (La Sara, 2001a). Hill (1994) reported that over $97 \%$ of $S$. serrata caught in the Gulf of Carpentaria, Australia were females, of these $61.5 \%$ were ovigerous.

Tidal cycle was apparent to influence relative abundance of $S$. serrata at all habitats. Relative abundance of $S$. serrata between flood and ebb tides differed significantly $(p<0.05)$. The high relative abundance during flood tide indicated that $S$. serrata moved forward to inshore and followed receding ebb tide to subtidal. This behavior is related with feeding activities of S. serrata (Hill et al., 1982; La Sara, 1994; La Sara, 2001a) that migrated into intertidal zone at high tide in order to feed. This was found at habitat $\mathbf{A}$. In the case of narrow intertidal flat, for instance at habitat B (Table 1), there is little scope for intertidal foraging and movement has to be confined to subtidal zone (Hyland et al., 1984).

Because its characteristics were suitable with requirement of $S$. serrata, relative abundance of both sexes was highest at habitat A (Figures 4 and 5). Aside from all characteristics discussed, food availability such as molluscs was abundant at habitat $\mathbf{A}$. Bivalves were collected by fishermen during ebb tide throughout the year. The characteristics of habitat $\mathbf{A}$ which differed with habitats $\mathbf{B}$ and $\mathbf{C}$ causing difference in relative abundance of $S$. serrata. However, relative abundance of $S$. serrata at habitat B was not significantly different with habitat $\mathbf{C}$ due to the number of individuals of $S$. serrata caught at both habitats were few (Figures 4 and 5).

When the data combined from all catches during flood and ebb tides that the relative abundances of $S$. serrata were distinguished into two peaks throughout the year. The major peak was in July and August (dry season) and minor peak in February (intermonsoon) (Figure 6). This location is affected by northern monsoon which starts in October and peaks in January and southern monsoon peaks in July - August 
(Sharp, 1996). There is intermonsoon between these two monsoons, in February and in September. When
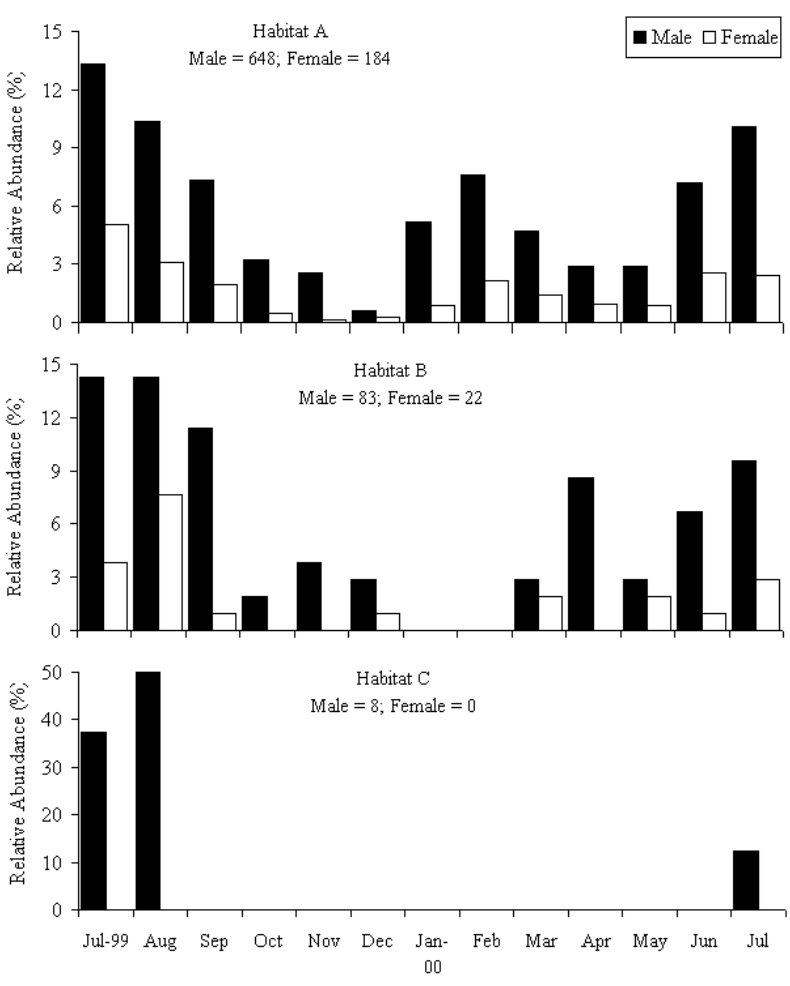

Fig.4. Relative abundance of males and females Scylla serrata at difference habitats during flood tide in Lawele Bay, Southeast Sulawesi intermonsoon season, the wind and waves are too strong and rage so it may affect distribution and relative abundance of
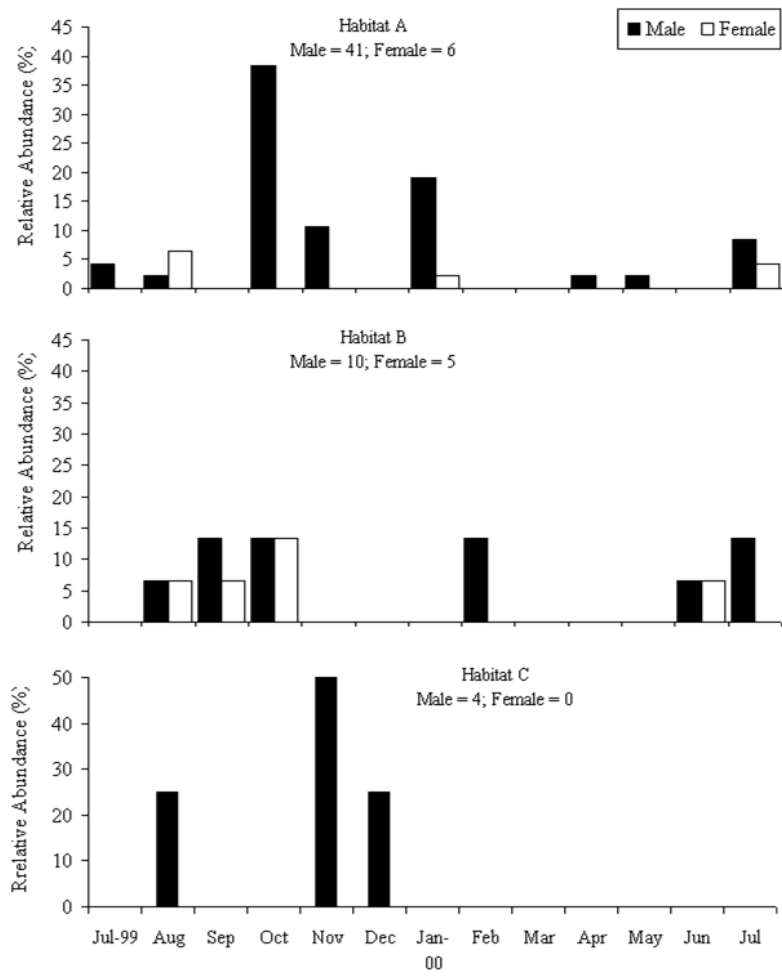

Fig.5. Relative abundance of males and females Scylla serrata at difference habitats during ebb tide in Lawele Bay, Southeast Sulawesi

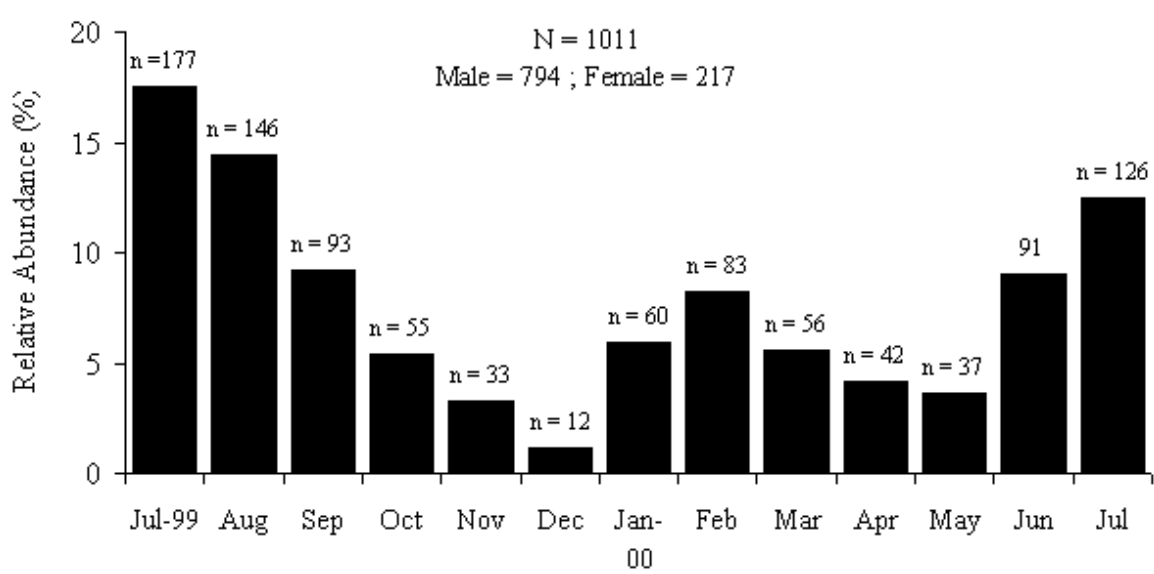

Fig.6. Relative monthly abundance Scylla serrata in Lawele Bay, Southeast Sulawesi (data of abundance of both sexes during flood and ebb tides combined)

S.serrata. The relative abundance of $S$. serrata in February was quite similar with the abundance in September.

During major peak abundance, $S$. serrata were caught mainly at habitats $\mathbf{A}$ and $\mathbf{B}$, while during minor peak abundance, they were caught only at habitat $\mathbf{A}$ (Figures 4 and 5). However, monthly relative abundance fluctuated gradually with similar trends. This presumably made these monthly relative abundances to be not significantly different $(p>0.05)$. Implication of these peak seasons on management of $S$. serrata population must be taken into account as far as sustainability is concerned. This could be regulated through the management of habitat and population. For instance, prohibition on catching juveniles and berried females is to maintain its population, while prevention on mangroves destruction is to maintain its habitats.

\section{ACKNOWLEDGMENTS}

We wish to thank Higher Education Program (HEP) of Indonesia-Asian Development Bank (ADB)-SEARCA that 
provided financial aid for research. Thank also due to all fishermen who had helped during research conducted, Dr. Saediman of Social Economics Agriculture Department of

\section{REFERENCES}

Bunt, J.S., Williams, W.T., Clay, H.J., 1982. River water salinity and the distribution of mangrove species along several rivers in North Queensland. Australian Journal of Botani, 30: 401-412. doi: 10.1071/BT9820401

Chandrasekaran, V.S., Natarajan, R., 1994. Seasonal abundance and distribution of seeds of mud crab Scylla serrata in Pichavaram mangrove, Southeast India. Journal of Aquatic Tropical, 9: 343-350.

Chong, V.C., Sasekumar, A., 1981. Food and feeding habits of the white prawn Penaeus merguiensis. Marine Ecology Progress Series, 5: 185191. doi: $10.3354 / \mathrm{meps} 005185$

Davenport, J., Wong, T.M., 1986. Responses of adult mud crabs (Scylla serrata, Forskal) to salinity and low oxygen tension. Comparative Biochemical and Physilogy, 86A: 43-47.

Heasman, M.P., Fielder, D.R., Shepherd, R.K., 1985. Mating and spawning in the mud crab, Scylla serrata (Forskal) (Decapoda: Portunidae), in Morton Bay, Queensland. Australian Journal of Marine Research, 36: 773-783. doi: 10.1071/MF9850773

Hill, B.J., 1975. Abundance, breeding and growth of the crab Scylla serrata in two South African Estuaries. Marine Biology, 32: 119-126. doi: 10.1007/BF00388505

Hill, B.J., 1976. Natural food, foregut clearance-rate and activity of the crab Scylla serrata. Marine Biology, 34: 109-116. doi: 10.1007/BF00390752

Hill, B.J., 1979. Biology of the mud crab Scylla serrata (Forskal) in the St Lucia system. Transacsation of the Royal Society South Africa, 44(1): 55-62. doi: 10.1080/00359197909520079

Hill, B.J., 1980. Effects of temperature on feeding and activity in the crab Scylla serrata. Marine Biology, 59: 189-192. doi: 10.1007/BF00396867

Hill, B.J., William, M.J., Dulton, P., 1982. Distribution of juvenile, subadult and adult Scylla serrata (Crustacea: Portunidae) on tidal flats in Australia. Marine Biology, 69: 117-120. doi: 10.1007/BF00396967

Hill, B.J (ed)., 1982. The Queensland mud crab fishery. Queensland Fish. Info. Ser. FI 8201. Queensland Department of Primary Industries, Queensland.

Hill, B.J., 1994. Offshore spawning by the portunid crab Scylla serrata (Crustacea: Decapoda). Marine Biology, 120: 379-384. doi: 10.1007/BF00680211

Hsueh, P.W., 1998. Salinity tolerance of hard stage Pinnotheres bidentatus (Decapoda: Brachyura: Pinnotheridae). Crustacean Research, 27: 8287

Hutching, P., Saenger, P., 1987. Ecology of mangrove. University of Queensland Press. St. Lucia, London, NY.

Hyland, S.J, Hill, B.J., Lee, C.P., 1984. Movement within and between different habitats by the portunid crab Scylla serrata. Marine Biology, 80 57-61. doi: 10.1007/BF00393128

Islam, M.J., Bhuiyan, A.L., 1982. Temperature tolerance and its impact on the distribution of mud crab in the Karnafully River Estuary. Bangladesh Journal of Agricultural, 6(4) \& 7(1): 38-46.

Islam, M.S., Shigemitsu, S., Nagai, T., 2000. Effects of salinity on the larval development of the mangrove dwelling semiterrestrial sesarmine crab Perisesarma bidens (De Haan). Crustacean Research, 29: 152-159.

Joel, D.R., Ray, P.J.S., 1980. Ecological distribution of some edible portunid crabs of the Pulicat Lake (Abstract). In: Symposium on coastal aquaculture, 12-18 January 1980, Cochin, India.

Keenan, C.P., Mann, D., Lavery, S., Davie, P., 1995. Genetic and morphological relationships of mud crabs, genus Scylla, from throughou
Halu Oleo University for correction on this manuscript, and Mr. Zulkarnaen of Forestry Department of Halu Oleo University for preparing Fig.1.

the Indo-Pacific. ACIAR Project Report. Department of Primary Industry, Queensland.

Keenan, C.P., Davie, P.J.F., Man, D.L., 1998. A revision of the genus Scylla De Haan, 1833 (Crustacea: Decapoda: Brachyura: Portunidae). The Raffles Bulletin of Zoology, 46(1): 217-245.

Keenan, C.P., 1999. The fourth species of Scylla. In: Keenan, C.P and Blackshaw, A. (eds). Mud crab aquaculture and biology. ACIAR Proceeding No.78. Australian Centre for International Agricultural Research, Canberra:48 - 58.

Kyomo, J., 1999. Distribution and abundance of crustaceans of commercial importance in Tanzania mainland coastal waters. Bulletin of Marine Science, 65(2): 321-335.

La Sara, 1994. The relationship between relative abundance of mud crab Scylla spp and habitat quality in Segara Anakan lagoon, Cilacap. MS Thesis, Bogor Agricultural University, Bogor. 78p.

La Sara, 1995. Habitat types of mud crabs Scylla spp in Segara Anakan Lagoon, Cilacap. Jurnal Agriplus (in Indonesia), 11(V): 27-37.

La Sara, 2001a. Ecology and fisheries of mud crab Scylla serrata in Lawele Bay, Southeast Sulawesi. PhD Dissertation, University of the Philippines in Visayas, lloilo, 198p.

La Sara, 2001b. Habitat and some biological parameters of two species of mud crab Scylla in Southeast Sulawesi, Indonesia. In: Carman O, Sulistiono, Purbayanto, A., Suzuki, A., Watanabe, S. and Arimoto, T. (eds). Proceeding of the JSPS-DGHE international symposium on fisheries science in tropical area. Tokyo University of Fisheries International JSPS Project. Tokyo, Japan Vol.10: 341-346.

La Sara, 2010. Study on the size structure and population parameters of mud crab Scylla serrata in Lawele Bay, Southeast Sulawesi, Indonesia. Journal of Coastal Development, 13(2): 133-147.

La Sara, Ingles, J.A., Aguilar, R.O., Laureta, L.V., Baldevarona, R.B. Watanabe, S., 2006. Abundance and distribution patterns of Scylla spp. larvae in the Lawele Bay, Southeast Sulawesi, Indonesia. Asian Fisheries Sciences, 19: 331-347.

La Sara, Aguilar, R.O., Laureta, L.V., Baldevarona, R.B., Ingles, J.A., 2007. The natural diet of the mud crab (Scylla serrata) in Lawele Bay, Southeast Sulawesi, Indonesia. The Philippine Agricultural Scientist, 90(1): 6-14.

Mair, J.Mc.D., 1980. Salinity and water-type preference of four species of postlarval shrimp (Penaeus) from west Mexico. Journal of Experimental Marine Biology and Ecology, 45: 69-82. doi: 10.1016/0022-0981(80)90070-2

Martosubroto P., Naamin, N., 1977. Relationship between tidal forest (mangroves) and commercial shrimp production in Indonesia. Marine Research (in Indonesia), 18: 81-86.

Robertson, A.I., Duke, N.C. 1987. Mangroves as nursery sites: comparisons of the abundance and species composition of fish and crustaceans in mangroves and other nearshore habitats in tropical Australia. Marine Biology, 96: 193-206. doi: 10.1007/BF00427019

Robertson, W.D., 1989. Factors affecting catches of the crab Scylla serrata (Forskal) (Decapoda: Portunidae) in baited traps: soak time, time of day and accessibility of the bait. Estuarine, Coastal Shelf Science, 29: 161170. doi: $10.1016 / 0272-7714(89) 90005-X$

Seiple, W., 1979. Distribution, habitat preferences and breeding periods in the crustaceans Sesarma cinereum and S. reticulatum (Brachyura: Decapoda: Grapsidae). Marine Biology, 52: 77-86. doi: 10.1007/BF00386860 
Sharp, G.D. 1996. Oceanography of the Indonesian archipelago and adjacent areas, pp. 7 - 14. In: D. Pauly and P. Martosubroto (eds). Baselines studies of biodiversity: the fish resources of Western Indonesia. ICLARM Stud. Rev. 23: 312p.

Staples, D.J., Vance, D.J., Heales, D.S. 1985. Habitat requirements of juvenile penaeid prawns and their relationship to offshore fisheries. In Rothlisberg P.C., Hill, B.J. and Staples, D.J. (eds). Second Australian National Prawn Seminar, NPS2: Cleveland, Australia. 47-54.

Wahyuni, I. S., Ismail, W., 1981. Beberapa kondisi lingkungan perairan kepiting bakau (S. serrata, Forskal) di perairan Tanjung Pasir Tangerang. Jurnal Penelitian Perikanan Laut (in Indonesia), 38: 59-68.
Wahyuni, I.S., Sunaryo, 1981. Notes on Scylla serrata (Forskal) in Muara Dua, Segara Anakan, Cilacap. Paper presented in "Biology National Congress $5^{\text {th" }}, 26$ - 28 Juni 1981, Semarang.

Weinstein, M.P., Weiss, S.L., Walters, M.F., 1980. Multiple determination of community structure in shallow marsh habitats, Cape Fear River Estuary, North Carolina, USA. Marine Biology,58: 227-243. doi: $10.1007 / B F 00391880$

Whiting, N.H., Moshiri, G.A., 1974. Certain organism - substrate relationships affecting the distribution of Uca minax. Hydrobiologia, 44: 481-493. doi: $10.1007 / B F 00036312$

Zar, J.H., 1984. Biostatistical analysis, second edition. Prentice Hall, Inc., Englewood Cliffs, New Jersey. 